\title{
Dental Erosion by Beverages and Determination of Trace Elements in Teeth by Atomic Absorption Spectrometry
}

\author{
Safaa Sabri Najim*, Maiada Abdulla Adnan \\ Chemistry Department, College of Science, Misan University, Misan, Iraq \\ Email: "Safchem2000@yahoo.com
}

Received 19 June 2016; accepted 16 July 2016; published 19 July 2016

Copyright (C) 2016 by authors and Scientific Research Publishing Inc.

This work is licensed under the Creative Commons Attribution International License (CC BY). http://creativecommons.org/licenses/by/4.0/

(c) (i) Open Access

\section{Abstract}

The analysis of trace elements in human tooth for use as biomarkers continues to generate considerable interest in environmental and bioanalytical studies, medical diagnostic and forensic science. This study investigated concentrations of essential and toxic elements $\mathrm{Cn}, \mathrm{Cu}, \mathrm{Pb}, \mathrm{Ni}$, $\mathrm{Co}$ and Cd) using flame atomic absorption spectroscopy (FAAS) and ( $\mathrm{Na}$ and $\mathrm{K}$ ) flame atomic emission spectroscopy (FAES) in human tooth obtained from Misan province, Iraq. The influence of smoking habits and born children on the levels of trace elements in additional to dental erosion by some beverages in the tooth samples were investigated. The overall of mean concentrations of ( $\mathrm{Zn} 185.2$ ppm, Cu 36.11 ppm, Pb 18.63 ppm, Ni 13.44 ppm, Co 3.45 ppm, and Cd 0.58 ppm, Na 11.683 ppm and K 115.27 ppm), (Zn 178.243 ppm, Cu 35.877 ppm, Pb 15.64 ppm, Ni 12.89 ppm, Co 3.421 ppm, Cd $0.455 \mathrm{ppm}$, Na 11,558.04 ppm and $\mathrm{K} 114.04 \mathrm{ppm}$ ) in smokers and non-smokers tooth groups respectively, (Zn 81.12 ppm, Cu 24.37 ppm, Pb 11.18 ppm, Ni 13.68 ppm, Co 3.32 ppm, Cd 0.44 ppm, Na 8227 ppm and K 76.42 ppm), (Zn 80.58 ppm, Cu 24.30 ppm, Pb 10.86 ppm, Ni 12.74 ppm, Co $2.71 \mathrm{ppm}, \mathrm{Cd} 0.23 \mathrm{ppm}, \mathrm{Na} 8165 \mathrm{ppm}$ and $\mathrm{K} 72.80 \mathrm{ppm}$ ) in mothers and wives tooth groups respectively. However the $\mathrm{w} / \mathrm{w} \%$ loss of tooth immersed in following order of beverages (green tea, black tea, cinnamon, hibiscus, vinegar and citrus aurantifolia $(9.09,9.68,12.36,15.01,16.77$ and 17.38), $(8.19,8.25,9.76,13.37,14.02$ and 15.33) in smokers and non-smokers groups respectively, $(11.25,11.47,13.30,15.75,19.58$, and 20.91), $(8.31,7.96,11.39,13.49,17.40$, and 17.67) in mothers and wives groups respectively. However, there is a statistically significant variance found $\mathrm{Zn}$ $\left(t_{c a l} 5.029, t_{t a b} 2.131\right), \mathrm{Pb}\left(t_{c a l} 4.8538, t_{t a b} 2.131\right), \mathrm{Ni}\left(t_{c a l} 5.243, t_{t a b} 2.131\right), \mathrm{Cd}\left(t_{c a l} 3.9062, t_{t a b} 2.131\right)$ and $\mathrm{Na}\left(t_{c a l} 3.0832, t_{t a b} 2.131\right)$ between smokers and non-smokers tooth groups. However, the Co $\left(t_{c a l} 2.7403, t_{t a b} 2.131\right.$ ) also shows statistically significant variance between mothers and wives groups. There is no statistically significant variance in $\mathrm{w} / \mathrm{w} \%$ loss after immersed the tooth in some beverages but in general it was higher in smokers than non-smokers and in mothers higher than wives.

${ }^{*}$ Corresponding author.

How to cite this paper: Najim, S.S. and Adnan, M.A. (2016) Dental Erosion by Beverages and Determination of Trace Elements in Teeth by Atomic Absorption Spectrometry. American Journal of Analytical Chemistry, 7, 548-555.

http://dx.doi.org/10.4236/ajac.2016.77050 


\section{Keywords}

\section{Flame Atomic Absorption Spectroscopy, Flame Atomic Emission Spectroscopy, Trace Element Concentrations, Biomarker}

\section{Introduction}

Biomonitoring of trace elements in human teeth has become an important tool to evaluate an individual's nutritional and environmental status [1]-[5]. Trace elements can be ingested by humans via different routes, including ingestion in the food and water or by deliberate consumption of soil and by dermal absorption. The presence and/or absence of trace elements in the environment influences their availability to humans [1]. For example, in the rural areas of Finland, the concentrations of $\mathrm{Zn}$ and $\mathrm{Mg}$ found in human dentine correlate with their concentrations in the soil [6], and dental fluorosis has been linked to the concentrations of fluoride $\mathrm{F}$ and $\mathrm{Pb}$ present in the drinking water [1] [4]. The concentration of $\mathrm{Pb}$ in the teeth can be used as an index of environmental pollution [7]. This element is preferentially incorporated and stored in calcified tissues, such as the teeth [8]. $\mathrm{Pb}$ concentration above $4 \mathrm{mg} / \mathrm{kg}$ in teeth has been suggested as being indicative of $\mathrm{Pb}$ toxicity [5] [9].

Sources of Cd include emissions from fuel combustion, tobacco smoke, phosphate fertilizer, sewage sludge, metal smelting, and disposal of metal waste. Other sources include the use of $\mathrm{Cd}$ for industrial applications, such as in the production of pigments, stabilizers, and alloys. In addition, $\mathrm{Cd}$ is present in trace amounts in certain foods, such as leafy vegetables, potatoes, grains and seeds, liver and kidney, and crustaceans and molluscs. Exposure to environmental $\mathrm{Cd}$ has been linked with an increased risk of dental caries [10]. Other studies have demonstrated that nutritional deficiencies can be detected by analyzing the chemical composition of teeth and that such deficiencies can affect teeth during dentition, which is a critical growth period for teeth [6]-[8] [11][14]. Differences in the availability of foods and food choices, which are often influenced by social and cultural practices, may be important factors in determining which trace elements are ingested by humans and can complicate any attempts at changing dietary habits to alter the intake of trace elements [14].

The extracted healthy permanent molars teeth in total were collected due to periodontal disease or orthodontic treatment between 18 and 50 of age, 64 teeth for trace elements analysis, and 72 teeth for beverages erosion, by private dental clinics in Misan province, $16.072 \mathrm{Km}^{2}$ in area, with a population 1,412,234. All samples were divided into four groups, according to the men smoking habits and women got children. The principal aim of this study was to investigate the trace elements content in the groups. In additional to monitor the influence of following beverages, green tea $(\mathrm{pH}=6.2)$, black tea $(\mathrm{pH}=5.5)$, cinnamon $(\mathrm{pH}=5.4)$, hibiscus $(\mathrm{pH}=2.8)$, vinegar $(\mathrm{pH}=2.4)$, and citrus aurantifolia $(\mathrm{pH}=2.1)$ on the dental erosion.

\section{Materials and Methods}

\subsection{Instrumentation}

Aurora atomic absorption spectrophotometer model (AI-1200) was used with an air-acetylene burner (slot length $11 \mathrm{~cm}$ ). Instrument setting were: lamp current, $10 \mathrm{~mA}$, slit width, $0.2 \mathrm{~nm}$, air flow, $1.8 \mathrm{~L} / \mathrm{min}$, ignition flow 2.4 $\mathrm{L} / \mathrm{min}$. These conditions were maintained constant throughout the measurements and Jenway PFP7 flame photometer was used with LPG liquid petroleum gas for sodium and potassium determination. The operating conditions adjusted according to the standard guidelines of the manufacturers. The quantitative determinations of the elements in samples were done by using calibration curves which obtained from diluted stock standard elements $1000 \mathrm{mg} / \mathrm{L}$. The concentrations of the analytes were obtained directly from the FAAS, but through the linear regression's equations after the correction of the absorbance signal from the blank as shown in Table 1.

\subsection{Reagents}

A standard solution of each element was prepared immediately by dilution of $1000 \mathrm{mg} / \mathrm{L}$ stock solution (sigma aldrich) prior to use. Deionized water was used throughout this experiment. All solvents and reagents such as $\mathrm{HNO}_{3}, \mathrm{H}_{2} \mathrm{O}_{2}$ were analytical reagent (AnalaR) grade. 
Table 1. Operating parameters of FAAS, wavelength, slit width, (HCL) current, flame and limit of detection (LOD) for each element.

\begin{tabular}{ccccccc}
\hline & \multicolumn{5}{c}{ Elements } \\
\cline { 2 - 7 } Parameters & $\mathrm{Cu}$ & $\mathrm{Zn}$ & $\mathrm{Co}$ & $\mathrm{Pb}$ & $\mathrm{Ni}$ & $\mathrm{Cd}$ \\
\hline Wave length (nm) & 324.7 & 213.9 & 240.7 & 217.0 & 232.0 & 228.8 \\
Slit widith (nm) & 0.2 & 0.2 & 0.2 & 0.2 & 0.2 & 0.2 \\
HCL amp current (mA) & 6 & 5 & 7 & 5 & 7 & 5 \\
Flame & Air/acetylene & Air/acetylene & Air/acetylene & Air/acetylene & Air/acetylene & Air/acetylene \\
LOD (ppm) & 0.03 & 0.03 & 0.05 & 0.03 & 0.03 & 0.01 \\
\hline
\end{tabular}

\subsection{Samples Collection}

The teeth were collected from private dental clinics in Misan province. 64 healthy extracted molar teeth for trace elements analysis, 32 males teeth, 16 smokers group and 16 non-smokers, in contrast 32 female's teeth, 16 mothers teeth group and 16 wives teeth group. Furthermore 72 healthy molar teeth for immersion in beverages, three teeth from each group as classified above, immersed in each single beverage, 18 teeth from each group were used, and all teeth were labeled in dry cellophane bags.

\subsection{Preparation the Tooth Samples}

To prevent sample contamination, all laboratory glassware was cleaned with detergent solution then rinsed with $10 \%$ nitric acid, then rinsed with deionized water before use. Each tooth was soaked in a solution $10 \%(\mathrm{v} / \mathrm{v})$ hydrogen peroxide for 1 hour to remove any organic material, rinsed with deionized water, air dried, and weighed, some kept for immersion in beverages. The others teeth, each tooth digested with Aristar reagent for trace elements analysis, using $4 \mathrm{ml}$ of $70 \%(\mathrm{v} / \mathrm{v})$ nitric acid and $3 \mathrm{ml} 70 \%(\mathrm{v} / \mathrm{v})$ perchloric acid in a conical flask, heated on a hotplate in fume hood until a transparent liquid was produced which adjusted to $10 \mathrm{ml}$ with deionized water.

\subsection{Preparation the Beverages}

The commercially brewing drinks, prepared by grinding the dry clean (leaves, fruit, flowers, and cortex) by ceramic mortar and pistol, sieving by a sieve mesh, added to $150 \mathrm{ml}$ deionzed water in a $250 \mathrm{ml}$ beaker, filtered by a filter paper, collected in a conical flask $150 \mathrm{ml}$, the $\mathrm{pH}$ of the solutions monitored by the $\mathrm{pH}$ meter.

\subsection{Teeth Immersion}

Three dry molar teeth from each group were immersed in each single beverage for $(3,6,9,12$, and 15 days) respectively, with a slow shaking by a shaker during immersion, the teeth were dried on air and weight after each period time, the mean weight calculated.

\subsection{Stock Solutions for Trace Element Analysis}

Working range standard solutions used to construct calibration curves for each element were prepared by serial dilution of $1000 \mathrm{ppm}$ standard stock solutions of each element. The calibration curve for each element was constructed by plotting the absorbance obtained from FAAS analysis of the standard solution versus the element concentration in ppm. Each sample was analyzed in triplicate and the average of trace element concentrations in the tooth samples were calculated using the constructed calibration curves.

\section{Results and Discussion}

\subsection{Calibration Curves}

The trace elements concentrations in ppm obtained from the constructed calibration curves for the investigated trace elements in the tooth samples. Table 1 indicates the wavelength used for AAS elemental analysis, the limits of detection LOD which is defined as the minimum detectable amount of metal, was calculated using the equation: LOD $=3 \mathrm{~s} / \mathrm{m}$; where $\mathrm{s}$ is the signal of the blank and $\mathrm{m}$ is the slop of the calibration curve [15]. The trace 
of the element concentration varied widely in the tooth samples as demonstrated by the large range of trace element concentration.

\subsection{Trace Elements Concentration of Smokers and Non-Smokers Teeth Groups}

A summary of the levels of trace elements concentrations found in the Teeth of smokers and non-smokers are shown in Figure 1. The order of the mean trace elements concentrations in tooth samples of smokers group is $\mathrm{Zn}>\mathrm{Cu}>\mathrm{Pb}>\mathrm{Ni}>\mathrm{Co}>\mathrm{Cd}$. Overall mean concentrations of Zn (185.2 ppm), Cu (36.11 ppm), Pb (18.63 ppm), Ni (13.44 ppm), Co (3.45 ppm) Cd (0.58) in smokers, in contrast, corresponding mean levels of Zn (178.24 ppm), Cu (35.87 ppm), Pb (15.64 ppm), Ni (12.89 ppm), Co (3.42 ppm) and Cd (0.45 ppm) were obtained in non smokers. To evaluate the differences between the mean trace element concentrations obtained in smokers and non-smokers, the mean trace elements concentration obtained for the two categories were subjected to a statistical student t-test analysis.

At a 95\% confidence level, there were significant differences between the mean concentration of $\mathrm{Zn}\left(t_{\text {cal }}\right.$ 5.029, $t_{\text {tab }}$ 2.131), $\mathrm{Cu}\left(t_{c a l} 2.056, t_{\text {tab }} 2.131\right) \mathrm{Pb}\left(t_{c a l} 4.8538, t_{\text {tab }}\right.$ 2.131), Ni $\left(t_{c a l} 5.243, t_{\text {tab }} 2.131\right)$, Co $\left(t_{c a l} 1.990, t_{\text {tab }}\right.$ 2.131), and Cd ( $\left.t_{c a l} 3.9062, t_{t a b} 2.131\right)$ obtained in smokers and non-smokers tooth groups respectively, as shown in Table 2.

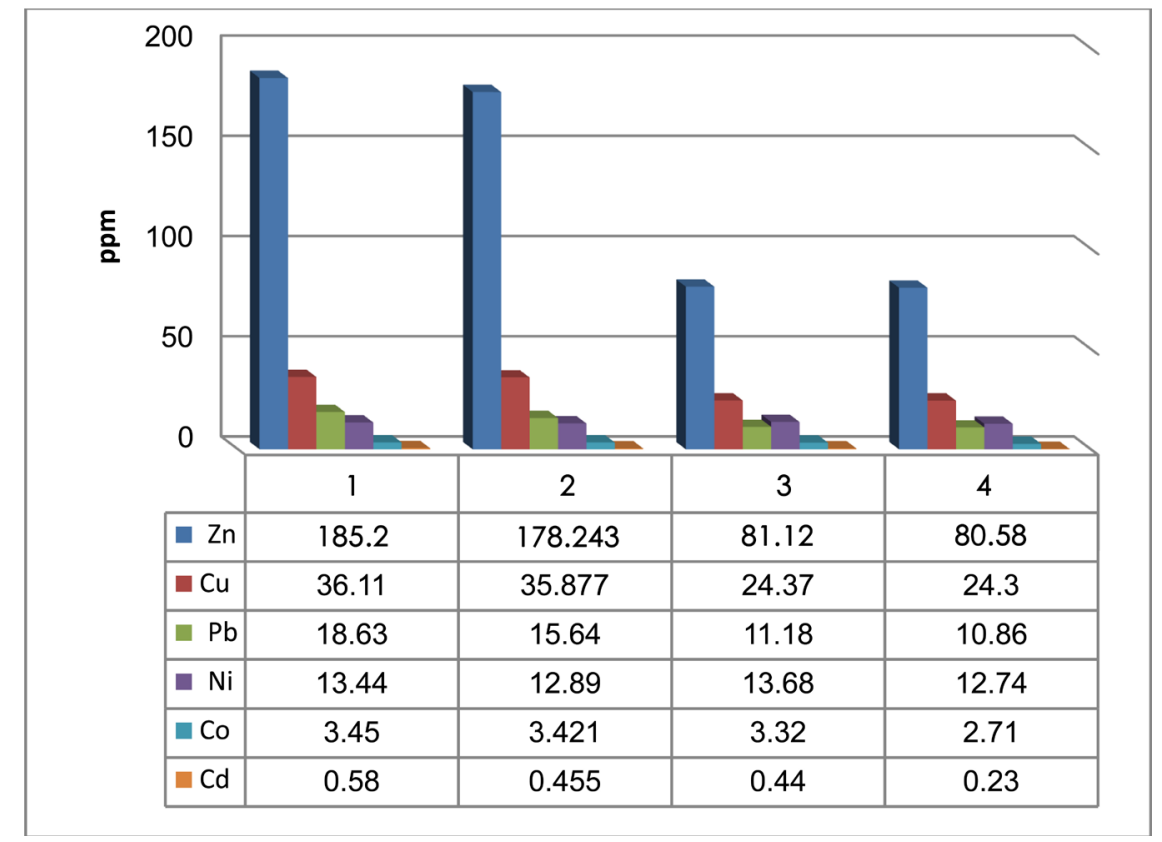

Figure 1. Concentrations of trace elements in ppm 1. smokers, 2. Non smokers, 3. Mothers and 4. Wives, healthy teeth groups, $(n=16)$.

Table 2. Concentrations of trace elements $(\mathrm{ppm})$ in smokers, non-smokers, mothers and wives, in healthy teeth groups, $(\mathrm{n}=$ 16).

\begin{tabular}{|c|c|c|c|c|c|c|}
\hline Elements & $\begin{array}{c}\text { Smokers } \\
\text { Mean } \pm \text { SD }\end{array}$ & $\begin{array}{c}\text { Non Smokers } \\
\text { Mean } \pm \text { SD }\end{array}$ & t-value & $\begin{array}{c}\text { Mothers } \\
\text { Mean } \pm \text { SD }\end{array}$ & $\begin{array}{c}\text { Wives } \\
\text { Mean } \pm \text { SD }\end{array}$ & t-value \\
\hline $\mathrm{Cd}$ & $0.58 \pm 0.10$ & $0.45 \pm 0.08$ & 3.9062 & $0.44 \pm 0.85$ & $0.23 \pm 0.31$ & 0.9284 \\
\hline Co & $3.45 \pm 0.05$ & $3.42 \pm 0.03$ & 1.9903 & $3.32 \pm 0.51$ & $2.71 \pm 0.73$ & 2.7403 \\
\hline $\mathrm{Ni}$ & $13.44 \pm 0.21$ & $12.89 \pm 0.03$ & 5.2430 & $13.68 \pm 2.75$ & $12.74 \pm 1.41$ & 1.2166 \\
\hline $\mathrm{Pb}$ & $18.63 \pm 1.97$ & $15.64 \pm 1.48$ & 4.8538 & $11.18 \pm 0.61$ & $10.86 \pm 0.82$ & 1.2524 \\
\hline $\mathrm{Cu}$ & $36.11 \pm 0.30$ & $35.87 \pm 0.34$ & 2.0560 & $24.37 \pm 0.12$ & $24.30 \pm 0.05$ & 2.1538 \\
\hline $\mathrm{Zn}$ & $185.20 \pm 4.25$ & $178.24 \pm 3.55$ & 5.0290 & $81.12 \pm 0.93$ & $80.58 \pm 0.54$ & 2.0089 \\
\hline $\mathrm{K}$ & $115.27 \pm 1.30$ & $114.04 \pm 2.10$ & 1.9922 & $76.42 \pm 3.10$ & $72.80 \pm 7.76$ & 1.7328 \\
\hline $\mathrm{Na}$ & $11683 \pm 120$ & $11,558.04 \pm 109$ & 3.0832 & $8227 \pm 70$ & $8165 \pm 98$ & 2.0592 \\
\hline
\end{tabular}




\subsection{Trace Element Concentrations of Mothers and Wives Teeth Groups}

Generally, Figure 1 shows the mean levels of the most trace elements were not significantly higher in mothers compared to wives. The mean levels of Zn (81.12 ppm), Cu (24.37 ppm), Ni (13.68 ppm), Pb (11.18 ppm), Co $(3.32 \mathrm{ppm})$ and $\mathrm{Cd}(0.44 \mathrm{ppm})$ respectively obtained in mothers. Interestingly the mean levels of Zn $(80.58 \mathrm{ppm})$, $\mathrm{Cu}(24.30 \mathrm{ppm}), \mathrm{Ni}(12.74 \mathrm{ppm}), \mathrm{Pb}(10.86 \mathrm{ppm})$, Co $(2.71 \mathrm{ppm})$ and $\mathrm{Cd}(0.23 \mathrm{ppm})$ respectively obtained in wives. The concentration of Co obtained in mothers was significantly and statistically different $(t>2.131)$ from the corresponding level in wives. At the 95\% confidence level, there were no significant differences $(\mathrm{t}<2.131)$ between the trace element concentrations obtained between mothers and wives.

The concentration of $\mathrm{Zn}\left(t_{c a l} 2.0089, t_{\text {tab }} 2.131\right)$, $\mathrm{Cu}\left(t_{c a l} 2.1538, t_{\text {tab }} 2.131\right) \mathrm{Pb}\left(t_{c a l} 1.2524, t_{\text {tab }} 2.131\right)$, Ni $\left(t_{c a l}\right.$ 1.2166, $\left.t_{\text {tab }} 2.131\right)$, Co $\left(t_{c a l} 2.7403, t_{\text {tab }} 2.131\right)$, Cd $\left(t_{c a l} 0.9284, t_{\text {tab }} 2.131\right)$ obtained in mothers and wives, as shown in Table 2.

The order of the mean concentrations of sodium and potassium in tooth samples of smokers group is $\mathrm{Na}>\mathrm{K}$, the mean levels of $\mathrm{Na}(11,683 \mathrm{ppm}), \mathrm{K}(115.27 \mathrm{ppm})$ respectively obtained in smokers and $\mathrm{Na}$ (11,558.04 ppm), $\mathrm{K}(114.04 \mathrm{ppm})$ in non-smokers, as shown in Figure 2 and Figure 3. The concentration of Na $\left(t_{c a l} 3.0832, t_{\text {tab }}\right.$ 2.131), $\mathrm{K}\left(t_{c a l} 1.9922, t_{t a b} 2.131\right)$ obtained in smokers and non-smokers so, the difference mean concentrations of Na between smokers and non smokers were significant as shown in Table 2.

On the other hand the mean concentration of sodium and potassium in tooth samples of mothers group is following the same previous order $\mathrm{Na}>\mathrm{K}$, the mean level of $\mathrm{Na}$ (8227 ppm), K (76.42 ppm), and Na (8165 ppm), $\mathrm{K}(72.80 \mathrm{ppm})$ respectively in wives group as shown in Figure 2 and Figure 3. There are no significant differ-

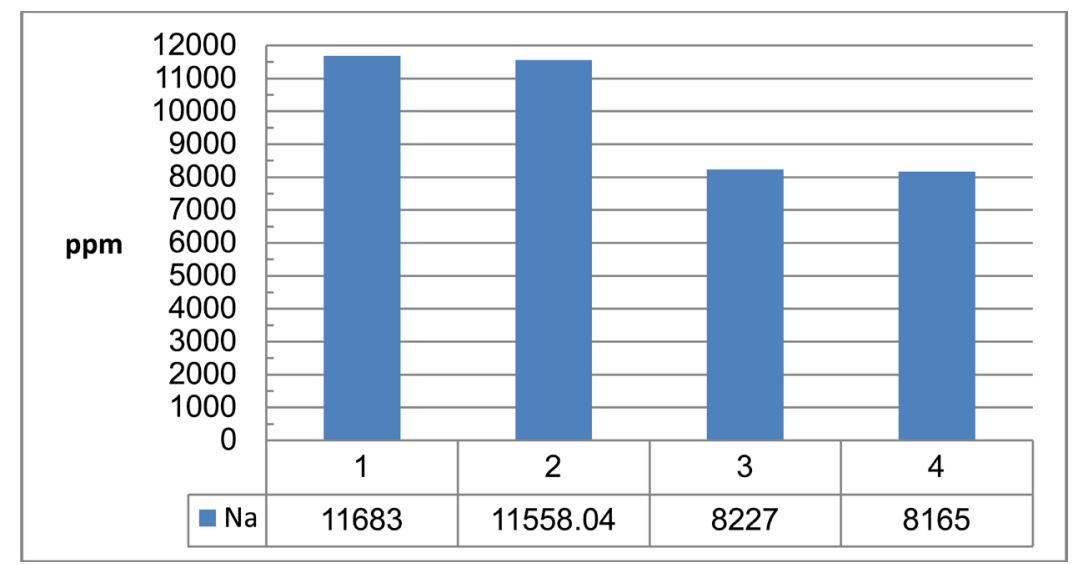

Figure 2. Concentrations of sodium in ppm 1. smokers, 2. non smokers, 3. mothers and 4. wives, healthy teeth groups $(\mathrm{n}=16)$.

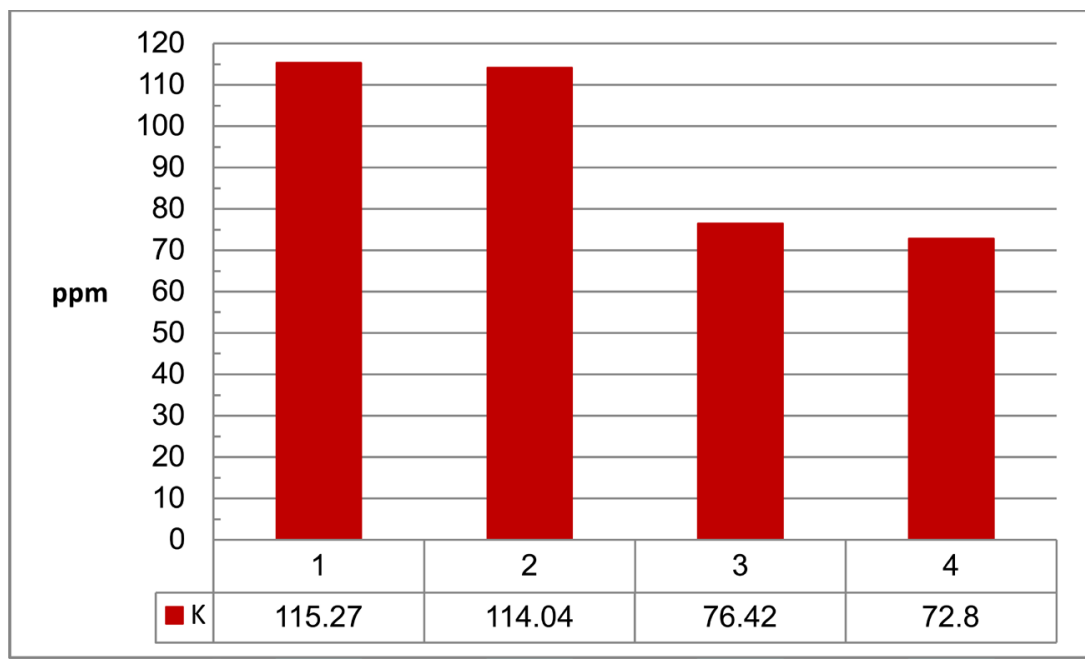

Figure 3. Concentrations of potassium in ppm 1. smokers, 2. non smokers, 3. mothers and 4. wives, healthy teeth groups. 
ences between concentrations of $\mathrm{Na}\left(t_{c a l} 2.0592, t_{\text {tab }} 2.131\right)$ and $\mathrm{K}\left(t_{c a l} 1.7328, t_{\text {tab }} 2.131\right)$ obtained in mothers and wives, as shown in Table 2.

\subsection{Effect of Beverages on the Dental Erosion of Smokers and Non-Smokers Teeth Groups}

The second part of the study was to determine the effect of some beverages on weight loss percentage of the smokers, non-smokers, mothers and wives tooth groups as shown in Table 3. The influence of the following beverages green tea $(\mathrm{pH}=6.2)$, black tea $(\mathrm{pH}=5.5)$, cinnamon $(\mathrm{pH}=5.4)$, hibiscus $(\mathrm{pH}=2.8)$, vinegar $(\mathrm{pH}=$ $2.4)$ and citrus aurantifolia $(\mathrm{pH}=2.1)$ on smokers, non-smokers, mothers and wives tooth groups.

Table 3 shows the influence of the beverages on the average weight loss percentage of smokers and nonsmokers tooth groups, the influence of beverages on smokers and non-smokers groups following the order green tea $(\mathrm{pH}=6.2)<$ black tea $(\mathrm{pH}=5.5)<$ cinnamon $(\mathrm{pH}=5.4)<$ hibiscus $(\mathrm{pH}=2.8)<$ vinegar $(\mathrm{pH}=2.4)<$ and citrus aurantifolia $(\mathrm{pH}=2.1)$, the average weight loss percentage of the smokers tooth, green tea $(\mathrm{pH}=6.2) \mathrm{w} / \mathrm{w} \%$ (9.09), black tea $(\mathrm{pH}=5.5) \mathrm{w} / \mathrm{w} \%(9.68)$, cinnamon $(\mathrm{pH}=5.4) \mathrm{w} / \mathrm{w} \%(12.36)$, hibiscus $(\mathrm{pH}=2.8) \mathrm{w} / \mathrm{w} \%$ (15.01), vinegar $(\mathrm{pH}=2.4) \mathrm{w} / \mathrm{w} \%$ (16.77) and citrus aurantifolia $(\mathrm{pH}=2.1) \mathrm{w} / \mathrm{w} \%$ (17.38) on the other hand for non-smokers green tea $(\mathrm{pH}=6.2) \mathrm{w} / \mathrm{w} \%(8.19)$, black tea $(\mathrm{pH}=5.5) \mathrm{w} / \mathrm{w} \%(8.25)$, cinnamon $(\mathrm{pH}=5.4) \mathrm{w} / \mathrm{w} \%$ (9.76), hibiscus $(\mathrm{pH}=2.8) \mathrm{w} / \mathrm{w} \%$ (13.37), vinegar $(\mathrm{pH}=2.4) \mathrm{w} / \mathrm{w} \%(14.02)$ and citrus aurantifolia $(\mathrm{pH}=2.1)$ w/w\% (15.33) as shown in Figure 4.

\subsection{Effect of Beverages on Dental Erosion of Mothers and Wives Teeth Groups}

Table 3 shows the influence of the beverages on the average weight loss percentage of mothers and wives tooth groups, the influence of beverages on mothers group following the order green tea $(\mathrm{pH}=6.2)<$ black tea $(\mathrm{pH}=$ $5.5)<$ cinnamon $(\mathrm{pH}=5.4)<$ hibiscus $(\mathrm{pH}=2.8)<\operatorname{vinegar}(\mathrm{pH}=2.4)<$ and citrus aurantifolia $(\mathrm{pH}=2.1)$, but for wives group are green tea $(\mathrm{pH}=6.2)>$ black tea $(\mathrm{pH}=5.5)<$ cinnamon $(\mathrm{pH}=5.4)<$ hibiscus $(\mathrm{pH}=2.8)<$ vinegar $(\mathrm{pH}=2.4)<$ and citrus aurantifolia $(\mathrm{pH}=2.1)$. The average weight loss percentage of the mothers tooth group, green tea $(\mathrm{pH}=6.2) \mathrm{w} / \mathrm{w} \%(11.25)$, black tea $(\mathrm{pH}=5.5 \mathrm{w} / \mathrm{w} \%(11.47)$, cinnamon $(\mathrm{pH}=5.4) \mathrm{w} / \mathrm{w} \%$ (13.30), hibiscus $(\mathrm{pH}=2.8) \mathrm{w} / \mathrm{w} \%(15.75)$, vinegar $(\mathrm{pH}=2.4) \mathrm{w} / \mathrm{w} \%(19.58)$ and citrus aurantifolia $(\mathrm{pH}=2.1)$

Table 3. Mean w/w\% loss of smokers, non-smokers, mothers, and wives teeth groups immersed in green tea, black tea, cinnamon, hibiscus, vinegar and citrus aurantifolia beverages $(n=3)$.

\begin{tabular}{cccccccc}
\hline Beverages & $\mathrm{pH}$ & $\begin{array}{c}\text { Smokers } \\
\text { Mean } \pm \text { SD }\end{array}$ & $\begin{array}{c}\text { Non Smokers } \\
\text { Mean } \pm \text { SD }\end{array}$ & t-value & $\begin{array}{c}\text { Mothers } \\
\text { Mean } \pm \text { SD }\end{array}$ & $\begin{array}{c}\text { Wives } \\
\text { Mean } \pm \text { SD }\end{array}$ \\
Green tea & 6.2 & $9.09 \pm 5.64$ & $8.19 \pm 5.71$ & 0.3957 & $11.25 \pm 6.51$ & $8.31 \pm 5.49$ \\
Black tea & 5.5 & $9.68 \pm 5.84$ & $8.25 \pm 5.36$ & 0.3344 & $11.47 \pm 6.24$ & $7.96 \pm 4.54$ & 0.1466 \\
Cinnamon & 5.4 & $12.36 \pm 6.81$ & $9.76 \pm 6.81$ & 0.2646 & $13.30 \pm 8.34$ & $11.39 \pm 6.98$ & 0.3379 \\
Hibiscus & 2.8 & $15.01 \pm 7.90$ & $13.37 \pm 7.64$ & 0.3608 & $15.75 \pm 7.86$ & $13.49 \pm 7.22$ & 0.3084 \\
Vinegar & 2.4 & $16.77 \pm 8.89$ & $14.02 \pm 8.68$ & 0.2999 & $19.58 \pm 11.16$ & $17.40 \pm 10.35$ & 0.3661 \\
Citrus aurantifolia & 2.1 & $17.38 \pm 9.05$ & $15.33 \pm 8.93$ & 0.3506 & $20.91 \pm 11.71$ & $17.67 \pm 10.61$ & 0.3135 \\
\hline
\end{tabular}

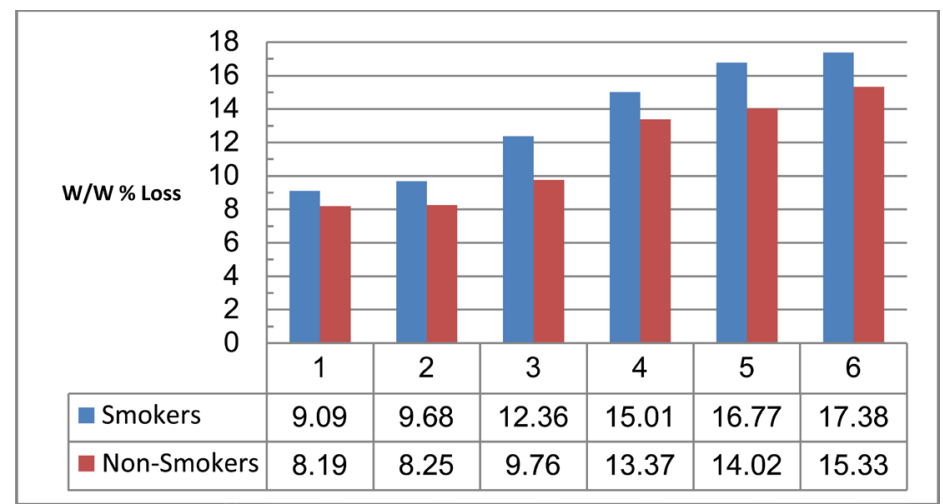

Figure 4. Mean w/w\% loss of smokers and non-smokers healthy tooth groups, immersed in 1. green Tea, 2. black tea, 3. cinnamon, 4. hibiscus, 5 . vinegar and 6. citrus aurantifolia, $(n=3)$. 


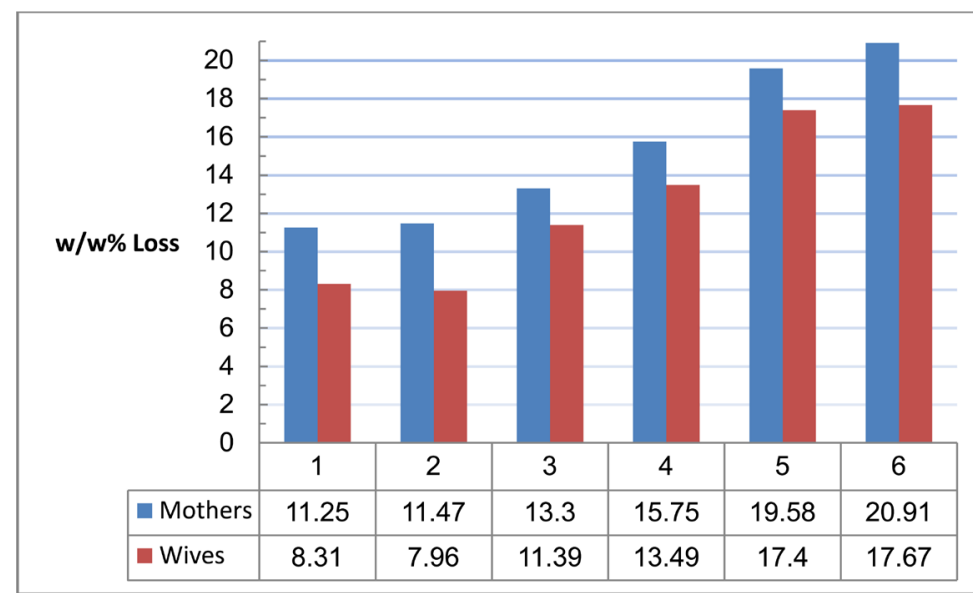

Figure 5. The mean w/w\% loss of mothers and wives healthy tooth groups, immersed in 1 . green tea, 2. black tea, 3. cinnamon, 4. hibiscus 5. vinegar and 6. citrus aurantifolia $(n=3)$.

$\mathrm{w} / \mathrm{w} \%$ (20.91), but for wives group are green tea $(\mathrm{pH}=6.2) \mathrm{w} / \mathrm{w} \%(8.31)$, black tea $(\mathrm{pH}=5.5 \mathrm{w} / \mathrm{w} \%(7.96)$, cinnamon $(\mathrm{pH}=5.4) \mathrm{w} / \mathrm{w} \%(11.39)$, hibiscus $(\mathrm{pH}=2.8) \mathrm{w} / \mathrm{w} \%(13.49)$, vinegar $(\mathrm{pH}=2.4) \mathrm{w} / \mathrm{w} \%(17.40)$ and citrus aurantifolia $(\mathrm{pH}=2.1) \mathrm{w} / \mathrm{w} \%$ (17.67) as shown in Figure 5.

Table 3 shows at the 95\% confidence level, there were no significant differences $(t<4.303)$ between the weight loss percentage of smokers and non-smokers tooth groups in following beverages, green tea $(\mathrm{pH}=6.2)$ $\left(t_{c a l} 0.3957, t_{\text {tab }} 4.303\right)$, black tea $(\mathrm{pH}=5.5)\left(t_{c a l} 0.3344, t_{\text {tab }} 4.303\right)$, cinnamon $(\mathrm{pH}=5.4)\left(t_{c a l} 0.2664, t_{\text {tab }} 4.303\right)$, hibiscus $(\mathrm{pH}=2.8)\left(t_{c a l} 0.3608, t_{\text {tab }} 4.303\right)$, vinegar $(\mathrm{pH}=2.4)\left(t_{c a l} 2.999, t_{\text {tab }} 4.303\right)$, and citrus aurantifolia $(\mathrm{pH}$ $=2.1)\left(t_{c a l} 0.3506, t_{\text {tab }}\right.$ 4.303), also there were no significant differences $(\mathrm{t}<4.303)$ between the weight loss percentage of mothers and wives tooth groups in following beverages, green tea $(\mathrm{pH}=6.2)\left(t_{c a l} 0.2086, t_{\text {tab }}\right.$ 4.303), black tea $(\mathrm{pH}=5.5)\left(t_{c a l} 0.1466, t_{\text {tab }} 4.303\right)$, cinnamon $(\mathrm{pH}=5.4)\left(t_{c a l} 0.3379, t_{\text {tab }} 4.303\right)$, hibiscus $(\mathrm{pH}=$ 2.8) $\left(t_{c a l} 0.3084, t_{\text {tab }} 4.303\right)$, vinegar $(\mathrm{pH}=2.4)\left(t_{c a l} 0.3661, t_{\text {tab }} 4.303\right)$, and citrus aurantifolia $(\mathrm{pH}=2.1)\left(t_{c a l}\right.$ 0.3135, $t_{\text {tab }}$ 4.303).

\section{Conclusions}

In general, this study shows that the mean levels of trace elements are found higher in smokers group than nonsmokers group. There are statistically significant differences concerning the elements $\mathrm{Zn}\left(t_{c a l} 4.871, t_{\text {tab }} 2.131\right)$, $\mathrm{Pb}\left(t_{c a l} 4.989, t_{\text {tab }}\right.$ 2.131), $\mathrm{Ni}\left(t_{c a l} 5.111, t_{\text {tab }} 2.131\right)$ and $\mathrm{Cd}\left(t_{c a l} 3.787, t_{\text {tab }}\right.$ 2.131) obtained in smokers and non-smokers.

On the other hand, we did not find any statistically differences in trace elements levels between mothers and wives groups except the Co $\left(t_{c a l} 2.654, t_{t a b} 2.131\right)$, but in general the trace elements levels found higher in mothers group than wives group.

The result showed that the tooth erosion by different beverages depended on the $\mathrm{pH}$ of the solution, which increased with lower $\mathrm{pH}$ value, concerning to the effect of direct attack by the hydrogen ion on the teeth.

There are no statistically significant differences of beverages effect on the teeth erosion between smokers and non-smokers groups, mothers and wives groups; but the teeth erosion of smokers was higher than non-smokers and the teeth erosion of mothers group was also higher than wives.

\section{Acknowledgements}

The authors would like to acknowledgment the private dental clinics in Misan province for their efforts during collecting the tooth samples.

\section{References}

[1] Brown, C.J., Chenery, S.R.N., Smith, B., Mason, C., Tomkins, A., Roberts, G.J., Sserunjogi, L. and Tiberindwa, J.V. (2004). Environmental Influences on the Trace Element Content of Teeth: Implications for Disease and Nutritional 
Status. Archives of Oral Biology, 49, 705-717. http://dx.doi.org/10.1016/j.archoralbio.2004.04.008

[2] Kaličanin, B.M. and Nikolić, R.S. (2008) Potentiometric Stripping Analysis of Zinc and Copper in Human Teeth and Dental Materials. Journal of Trace Elements in Medicine and Biology, 22, 93-99. http://dx.doi.org/10.1016/j.jtemb.2007.12.005

[3] Chew, L.T., Bradley, D.A., Mohd, A.Y. and Jamil, M.M. (2000) Zinc, Lead and Copper in Human Teeth Measured by Induced Coupled Argon Plasma Atomic Emission Spectroscopy (ICP-AES). Applied Radiation and Isotopes, 53, 633638. http://dx.doi.org/10.1016/S0969-8043(00)00243-8

[4] Grünke, K., Stark, H.J., Wennrich, R. and Franck, U. (1996) Determination of Traces of Heavy Metals (Mn, Cu, Zn, $\mathrm{Cd}$ and $\mathrm{Pb}$ ) in Microsamples of Teeth Material by ETV-ICP-MS. Fresenius' Journal of Analytical Chemistry, 354, 633-635.

[5] Al-Mahroos, F. and Al-Saleh, F.S. (1997) Lead Levels in Deciduous Teeth of Children in Bahrain. Annals of Tropical Paediatrics, 17, 147-154. http://dx.doi.org/10.1080/02724936.1997.11747878

[6] Lappalainen, R., Knuuttila, M. and Salminen, R. (1981) The Concentrations of Zn and Mg in Human Enamel and Dentine Related to Age and Their Concentrations in the Soil. Archives of Oral Biology, 26, 1-6. http://dx.doi.org/10.1016/0003-9969(81)90063-7

[7] Gulson, B. and Wilson, D. (1994) History of Lead Exposure in Children Revealed from Isotopic Analyses of Teeth. Archives of Environmental Health, 49, 279-283. http://dx.doi.org/10.1080/00039896.1994.9937480

[8] Martin, R.R., Naftel, S.J., Nelson, A.J., Feilen, A.B. and Narvaez, A. (2007) Metal Distributions in the Cementum Rings of Human Teeth: Possible Depositional Chronologies and Diagenesis. Journal of Archaeological Science, 34, 936-945. http://dx.doi.org/10.1016/j.jas.2006.09.018

[9] Carvalho, M.L., Karydas, A.G., Casaca, C., Zarkadas, C., Paradellis, T., Kokkoris, M., Nsouli, B. and Cunha, A.S. (2001) Fluorine Determination in Human Healthy and Carious Teeth Using the PIGE Technique. Nuclear Instruments and Methods in Physics Research Section B, 179, 561-567. http://dx.doi.org/10.1016/S0168-583X(01)00684-X

[10] Arora, M., Weuve, J., Schwartz, J. and Wright, R.O. (2008) Association of Environmental Cadmium Exposure with Pediatric Dental Caries. Environmental Health Perspectives, 116, 821-825. http://dx.doi.org/10.1289/ehp.10947

[11] Carvalho, M.L., Marques, A.F., Marques, J.P. and Casaca, C. (2007) Evaluation of the Diffusion of Mn, Fe, Ba and Pb in Middle Ages Human Teeth by Synchrotron Microprobe X-Ray Fluorescence. Spectrochimica Acta Part B, 62, 702706. http://dx.doi.org/10.1016/j.sab.2007.02.011

[12] Shafer, M.M., Siker, M., Overdier, J.T., Ramsl, P.C., Teschler-Nicola, M. and Farrell, P.M. (2008) Enhanced Methods for Assessment of the Trace Element Composition of Iron Age Bone. Science of the Total Environment, 401, $144-161$. http://dx.doi.org/10.1016/j.scitotenv.2008.02.063

[13] Budd, P., Montgomery, J., Cox, A., Krause, P., Barreiro, B. and Thomas, R.G. (1998) The Distribution of Lead within Ancient and Modern Human Teeth: Implications for Long-Term and Historical Exposure Monitoring. Science of the Total Environment, 220, 121-136. http://dx.doi.org/10.1016/S0048-9697(98)00244-7

[14] Shashikiran, N.D., Subba Reddy, V.V. and Hiremath, M.C. (2007) Estimation of Trace Elements in Sound and Carious Enamel of Primary and Permanent Teeth by Atomic Absorption Spectrophotometry: An in Vitro Study. Indian Journal of Dental Research, 18, 157-162. http://dx.doi.org/10.4103/0970-9290.35824

[15] Fakayode Sayo, O., Lanka, O.S., Pollard David, A. and Mamudu, Y. (2013) Use of Flame Atomic Absorption Spectroscopy and Multivariate Analysis for the Determination of Trace Elements in Human Scalp. American Journal of Analytical Chemistry, 4, 359. http://dx.doi.org/10.4236/ajac.2013.47044 


\section{Submit or recommend next manuscript to SCIRP and we will provide best service for you:}

Accepting pre-submission inquiries through Email, Facebook, LinkedIn, Twitter, etc.

A wide selection of journals (inclusive of 9 subjects, more than 200 journals)

Providing 24-hour high-quality service

User-friendly online submission system

Fair and swift peer-review system

Efficient typesetting and proofreading procedure

Display of the result of downloads and visits, as well as the number of cited articles

Maximum dissemination of your research work

Submit your manuscript at: http://papersubmission.scirp.org/ 